\title{
PENGARUH FASILITAS KERJA DAN KOMPETENSI TERHADAP KEPUASAN KERJA PEGAWAI DAN DAMPAKNYA TERHADAP KINERJA PEGAWAI KANTOR KELURAHAN SEKECAMATAN MUARA BULIAN KABUPATEN BATANG HARI
}

\author{
Budi Darma, Arna Suryani, Yunan Surono
}

\begin{abstract}
This study raised concerns about the effect of working facilities and competencies to job satisfaction and its impact on performance. The research was conducted within the scope of the District Muara Bulian precisely on the entire village.The performance of employees is among the key issues are constantly faced by the organization management. Therefore, among the tasks of the manager is a very important move employees to contribute to the success of the organization. The purpose of this study is to examine and determine the influence of working facilities, competencies, job satisfaction and performance. Influence of working facilities, competencies, job satisfaction and employee performance tested either directly or indirectly.To examine issues directly above the survey conducted by distributing questionnaires to employees village office. The results of the questionnaire were analyzed qualitatively and verification. Data analysis tool made by using Path Analysis. The results of this study indicate that the working facilities and competence have an influence on job satisfaction and have an impact on performance, both directly and indirectly.
\end{abstract}

Key word: working facilities, competencies, performance

\section{PENDAHULUAN}

Mengingat pentingnya peranan sumber daya manusia ini dalam suatu organisasi tentunya sumber daya manusia tersebut perlu untuk dikelola sedemikian rupa, dan hal ini merupakan bagian penting dari pekerjaan menejemen organisasi yang bersangkutan. Menurut Robins (2002), proses manejemen sumber daya manusia pada akhirnya harus diukur dari segi seberapa efektif para menejer mengelola sumbe rdaya manusia yang dimiliki. Dalam konteks ini, pengelolaan sumber daya manusia yang efektif tercermin dari produktivitas atau kinerja yang disumbangkan oleh pegawai. Dengan demikian dapatlah dikatakan bahwa kinerja dari para pegawai merupakan diantara isu-isu pokok yang senantiasa dihadapi oleh menejemen organisasi. Karena itu, diantara tugas-tugas para menejer yang sangat penting adalah menggerakkan para pegawai guna memberi kontribusi bagi keberhasilan organisasi. Setiap Kantor Kelurahan tentu saja menyediakan fasilitas kerja untuk memberikan pelayanan yang optimal kepada masyarakat. Fasilitas kerja tersebut meliputi fasilitas alat kerja, fasilitas perlengkapan kerja, dan fasilitas sosial. Jika dari segi jumlah fasilitas alat kerja, dirasa cukup untuk memenuhi kebutuhan dalam menyelesaikan pekerjaan. Namun, jika diperhatikan lebih dalam lagi, ada hal yang berkemungkinan perlu diperhatikan lagi, seperti untuk urusan mencetak, terkadang satu bidang di kantor kelurahan harus mencetak diruangan lain karena printer yang ada di ruangannya tidak bisa mencetak warna. Kemudian ada lagi, jika ingin menscan dokumen, harus ke ruangan lain juga karena tipe printer yang ia miliki hanya untuk cetak saja. Ini bisa menandakan bahwa fasilitas alat kerja belum secara optimal fungsinya pada Kantor Kelurahan Sekecamatan Muara Bulian.

Dengan kondisi fasilitas perlengkapan kerja yang ada, terkadang para karyawan sering merasa kepanasan pada siang hari. Hal ini dikarenakan air conditioner yang ada hanya satu unit, itu pun hanya ada di Ruangan Lurah sehingga kipas angin yang ada tidak memberikan efek sejuk secara optimal. Kemudian jumlah kipas angin yang ada pun belum sesuai dengan kondisi ruangan kantor dan jumlahnya dengan pegawai apalagi jika ditambah apabila ada masyarakat yang datang untuk meminta pelayanan dokumen kependudukan ataupun lainnya. Dengan failitas kerja yang ada, tentu saja fasilitas tersebut akan digunakan oleh tenaga kerja untuk mempermudah pekerjaan. Namun bisa dibayangkan jika tenaga kerja tidak mampu untuk menggunakan fasilitas tersebut. Maka dalam penggunaan fasilitas juga harus didukung dengan kompetensi yang cakap dalam menggunakan fasilitas yang ada. Konsep kompetensi mulai menjadi tren dan banyak diperbincangkan sejak tahun 1993 dan saat ini menjadi sangat populer terutama di lingkungan perusahaan multinasional dan nasional yang modern. Menurut Edy Sutrisno (2009), Wood dan Payne mengemukakan istilah konsep kompetensi.

Pengaruh Fasilitas Kerja dan Kompetensi terhadap Kepuasan Kerja Pegawai dan Dampaknya Terhadap Kinerja Pegawai Kantor Kelurahan Sekecamatan Muara Bulian Kabupaten Batang Hari 
Sebenarnya telah diperkenalkan sejak tahun 1982 oleh Richard Boyatzis seorang penulis manajemen asal Amerika Serikat dalam bukunya The Competent Manager.

Peningkatan kemampuan merupakan strategi yang diarahkan untuk meningkatkan efisiensi, efektivitas dan sikap tanggap dalam rangka peningkatan kinerja organisasi secara keseluruhan. Adapun dimensi-dimensi dari peningkatan kemampuan ini dapat berupa upaya pengembangan sumber daya manusia, pengetahuan organisasi, dan reformasi kelembagaan. Dalam menghadapi perkembangan lingkungan organisasi, menuntut kesiapan sumber daya manusia organisasi untuk memiliki kemampuan dalam menjawab tantangan tersebut dengan menunujukkan kinerjanya melalui kegiatan-kegiatan dalam bidang tugas dan pekerjaannya dalam bidang organisasi. (Adisetiawan, 2014)

Dalam rangka operasional, kompetensi tersebut membuat sumber daya manusia mampu menggali potensi sumber daya-sumber daya lainnya yang dillimiki oleh organisasi, mampu mengefektifkan dan mengefisiensi proses produksi di dalam organiasi serta mampu menghasilkan ouput yang sesuai dengan tujuan organisasi. Kesemuanya ini tentu saja pada akhirnya akan memberikan nilai tambah bagi organisasi secara keseluruhan. Kompetensi tersebut mampu terwujud melalui pendidikan dan pelatihan atau juga dari pengalaman selama bekerja pada bidang yang ia jalani. Pada kenyataannya terkadang masih ada dari para pegawai yang belum mahir dalam mengoperasikan komputer dan mengatasi masalah yang terjadi ketika mesin cetak mengalami masalah. Bahkan untuk sekedar mengatasi masalah jika terjadi error karena selang infus terjepit banyak yang tidak bisa mengatasinya. Jika dibandingkan dengan kondisi jenjang pendidikan dan keahlian di lapangan, bisa peneliti katakan bahwa kompetensi pegawai Kantor Kelurahan Sekecamatan Muara Bulian cukup baik.

Kepuasan tenaga kerja dalam suatu organisasi pada umumnya tentu dapat tercermin dari seberapa banyak tenaga kerja yang merasa senang dan betah bekerja dalam organisasi. Untuk mengetahui kepuasan kerja pada Kantor Kelurahan yang ada di dalam Kecamatan Muara Bulian, maka peneliti melakukan observasi terhadap beberapa indikator kepuasan kerja dengan kenyataan di lapangan. Untuk indikator kepuasan promosi, para pegawai menilai promosi yang ada tidak berdasarkan kinerja. Hanya berdasarkan kedekatan emosional politik. Sehingga ketika terjadi pergantian kepala daerah, banyak para pegawai yang merasa cemas dipindahkan ke posisi atau ke lokasi yang menurut mereka kurang strategis. Untuk kepuasan rekan kerja, ada sebagian pegawai yang mengeluhkan tentang sikap profesionalitas rekan kerja mereka. Pekerjaan yang seharusnya diselesaikan bersama rekan kerja hanya diselesaikan oleh satu pegawai saja. Berdasarkan hal-hal ini, peneliti menarik kesimpulan bahwa kepuasan kerja pegawai Kantor Kelurahan Sekecamatan Muara Bulian belum sepenuhnya baik.

Pencapaian kerja Kantor Kelurahan Sekecamatan Muara Bulian sudah 100\%. Jika ditinjau dari sisi kuantitas memang sudah terpenuhi mencapai $100 \%$, namun dari sisi kualitas masih belum begitu baik, ada beberapa pekerjaan yang harusnya bisa selesai dalam hitungan jam, mereka selesaikan dalam beberapa hari dengan alasan yang tak tentu. Misalnya, untuk pembuatan permohonan akta kelahiran terkadang bisa sampai dua hari dengan alasan Pak Lurah tidak sedang di tempat. Berdasarkan hal ini, kinerja pegawai menurut peneliti cukup baik.

\section{Tinjauan Pustaka \\ Fasilitas Kerja}

Fasilitas merupakan segala hal yang dapat memudahkan dan melancarkan pelaksanaan kegiatan, yang dapat memudahkan kegiatan dapat berupa sarana dan prasarana. Kamus Besar Bahasa Indonesia (2008:389), fasilitas adalah sarana melancarkan pelaksanaan fungsi. Fasilitas adalah sarana untuk melancarkan dan memudahkan pelaksanaan fungsi. Fasilitas merupakan komponen individual dari penawaran yang mudah ditumbuhkan atau dikurangi tanpa mengubah kualitas dan model jasa. Fasilitas juga merupakan alat untuk membedakan program lembaga yang satu dari pesaing yang lainnya ( Lupiyoadi, $2006: 150$ ).

Moenir (2003) menyatakan "fasilitas merupakan segala sesuatu yang digunakan, dipakai, ditempati, oleh pegawai baik dalam hubungan lingkungan dengan pekerjaan maupun untuk kelancaran pekerjaan. Menurut Moenir (2003) dari pengertian fasilitas di atas maka dapat dibagi tiga golongan besar yaitu: Fasilitas Alat Kerja, Fasilitas Perlengkapan Kerja, dan Fasilitas Sosial. Fasilitas yang dimaksud dalam 
penelitian ini adalah bagaimana pemanfaatan dan kelengkapan fasilitas kerja yang menunjang kepuasan kerja dan kinerja para pegawai Kantor Kelurahan di Kecamatan Muara Bulian. Dalam penelitian ini digunakan indikator dari variabel fasilitas kantor yaitu fasilitas alat kerja dan fasilitas perlengkapan kerja.

\section{Kompetensi}

Menurut Boulter et al. (dalam Rosidah, 2003:11), kompetensi adalah karakteristik dasar dari seseorang yang memungkinkan pegawai mengeluarkan kinerja superior dalam pekerjaannya. Berdasarkan uraian di atas makna kompetensi mengandung bagian kepribadian yang mendalam dan melekat pada seseorang dengan perilaku yang dapat diprediksi pada berbagai keadaan dan tugas pekerjaan. Prediksi siapa yang berkinerja baik dan kurang baik dapat diukur dari kriteria atau standar yang digunakan. Menurut Mc Acshan dalam Sutrisno (2010: 203) memberikan pengertian kompetensi sebagai pengetahuan, keterampilan, dan kemampuan yang dikuasai oleh seseorang yang telah menjadi bagian dari dirinya, sehingga ia dapat melakukan perilakuperilaku kognitif, afektif, dan psikomotorik dengan sebaik-baiknya. Apabila kompetensi diartikan sama dengan kemampuan, maka dapat diartikan pengetahuan memahami tujuan bekerja, pengetahuan dalam melaksanakan kiat-kiat jitu dalam melaksanakan pekerjaan yang tepat dan baik, serta memahami betapa pentingnya disiplin dalam organisasi agar semua aturan dapat berjalan dengan baik. Indikator kompetensi yang dikemukakan oleh Sutrisno (2010) adalah sebagai berikut : 1. Pengetahuan, 2. Pemahaman, 3. Nilai, 4. Kemampuan, 5. Sikap, dan 6. Minat

\section{Kepuasan Kerja}

Hasibuan (2008:202), menyatakan bahwa kepuasan kerja adalah sikap emosional yang menyenangkan dan mencintai pekerjaanya. Sikap ini dicerminkan oleh moral kerja, kedisiplinan, dan prestasi kerja. Berdasarkan definisi diatas, indikator kepuasan kerja adalah : 1. Menyenangi pekerjaannya, 2. Mencintai pekerjaannya, 3. Moral kerja, 4. Kedisiplinan, dan 5. Prestasi kerja.

\section{Kinerja}

Menurut Gomes (2003: 195) mengemukakan definisi kinerja pegawai sebagai ungkapan seperti output, efisiensi serta efektivitas sering dihubungkan dengan produktivitas. Ada beberapa indikator pengukuran kinerja pegawai menurut Gomes (2003: 134) adalah sebagai berikut :

1. Quantity of work: Jumlah kerja yang dilakukan dalam suatu periode waktu yang ditentukan.

2. Quality of work : kualitas kerja yang dicapai berdasarkan syarat-syarat kesesuaian dan kesiapannya.

3. Job Knowledge : Luasnya pengetahuan mengenai pekerjaan dan keterampilannya.

4. Creativeness : Keaslian gagasan-gagasan yang dimunculkan dari tindakan-tindakan untuk menyelesaikan persoalan-persoalan yang timbul.

5. Cooperation : kesediaan untuk bekerja sama dengan orang lain (sesama anggota organisasi).

6. Dependability : Kesadaran dan dapat dipercaya dalam hal kehadiran dan penyelesaian kerja tepat pada waktunya.

7. Initiative : Semangat untuk melaksanakan tugas-tugas baru dan dalam memperbesar tanggung jawabnya.

8. Personal Qualities : Menyangkut kepribadian, kepemimpinan, keramah-tamahan, dan integritas pribadi.

\section{METODE}

Adapun objek penelitian dari penelitian ini adalah seluruh Kantor Kelurahan yang ada di dalam lingkup Kecamatan Muara Bulian. Adapun kantor tersebut adalah Kantor Kelurahan Muara Bulian, Kantor Kelurahan Pasar Baru, Kantor Kelurahan Rengas Condong, Kantor Kelurahan Teratai, dan Kantor Kelurahan Sridadi. Untuk menentukan besarnya sampel yang akan dijadikan responden, peneliti mengacu pada pendapat Arikunto (2010). Arikunto dalam melakukan perhitungan ukuran sampel yang diperoleh menyatakan bahwa apabila populasi di bawah 100 maka diambil semuanya untuk dijadikan sampel. Tapi jika populasi di atas 100 maka diambil 10-25\%. Dalam hal ini populasi berjumlah 67 orang, maka sampelnya pun juga berjumlah 67 orang. Data primer adalah data yang diperoleh dengan cara penelitian dilapangan, yaitu data diperoleh dari para pegawai Kantor Kelurahan Sekecamatan Muara Bulian Kabupaten Batang Hari dengan melakukan 
penyebaran kusioner. Data Sekunder adalah data yang diperoleh dengan cara mengadakan penelitian kepustakaan dan dokumen kepegawaian, dokumen kerja, dan dokumen lainnya yang berasal dari tiap Kantor Kelurahan. Dalam memperoleh data, digunakan metode survey yaitu dengan menggunakan perangkat kuesioner terstruktur yang diajukan pada responden. Format kuesioner terdiri dari dua bagian utama, bagian pertama menyangkut pertanyaan-pertanyaan umum mengenai karakteristik pegawai dan bagian kedua berisi pertanyaan masalah pokok penelitian. Item-item pertanyaan diantaranya adalah seperti telah dikemukakan sebelumnya. Pengumpulan data dilakukan dengan pertama-tama meminta kesediaan para responden untuk berpartisipasi dalam penelitian ini, kemudian menyampaikan perangkat kuesioner penelitian untuk diisi oleh responden.

\section{Teknik Analisis Data}

1) Path Analysis

Untuk menjawab permasalahan menggunakan analisis jalur (Path Analysis) yang merupakan suatu metode pendekomposisian korelasi ke dalam bagian-bagian yang berbeda untuk menginterprestasikan suatu pengaruh/efek. Metode Path Analysis ini juga digunakan untuk menelaah hubungan antara model kausal yang dirumuskan atas dasar pertimbangan teoritis dan pengetahuan tertentu. Hubungan kausal selain didasarkan pada data, juga didasarkan pada pengetahuan, perumusan hipotesis dan analisis logis, sehingga dapat dikatakan Path Analysis ini dapat digunakan untuk menguji seperangkat hipotesis kausal serta untuk menafsirkan hubungan tersebut.

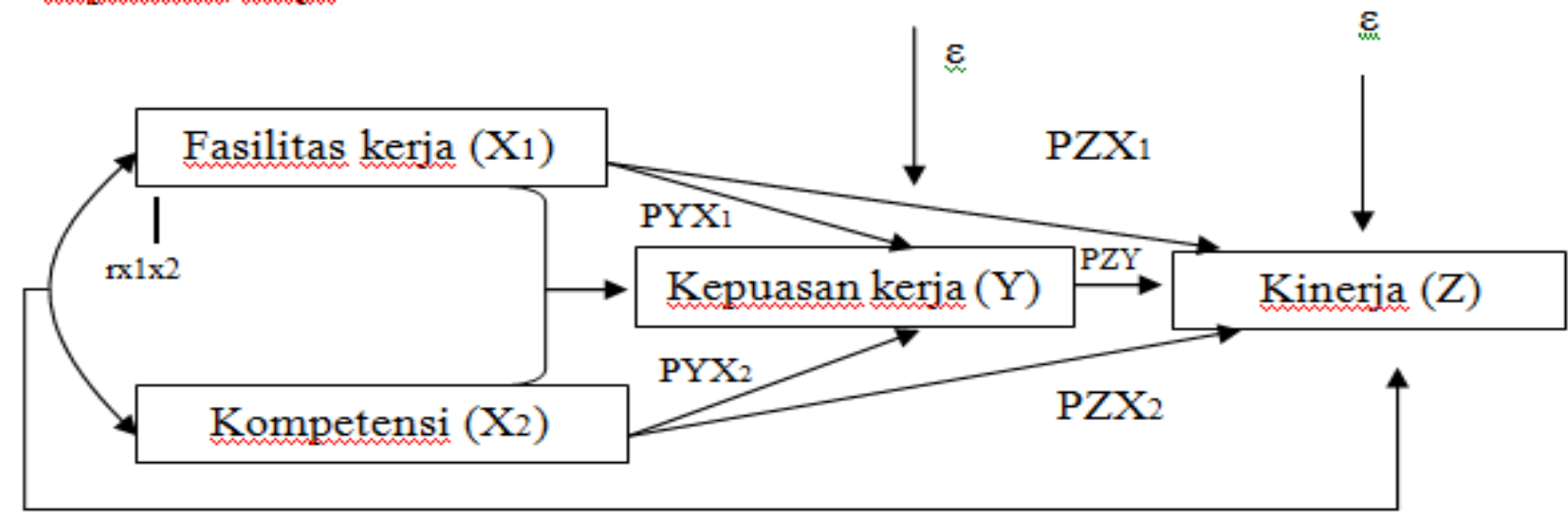

Gambar 1

Analisis Jalur

berikut :

Untuk persamaan hubungan struktural diagram jalur diatas dinyatakan dengan persamaan sebagai

- $\quad$ Pengaruh X1 ke Z melalui Y

Pengaruh langsung

$\mathrm{X} 1 \rightarrow \mathrm{Z} \Omega \mathrm{Y}=\mathrm{PZX} 1$. PYX1. PZY

Pengaruh tidak langsung

$\mathrm{X} 1 \rightarrow \mathrm{Z} \Omega \mathrm{X} 2 \Omega \mathrm{Y}=\mathrm{PZX} 1 . \mathrm{rx} 1 \mathrm{x} 2$. PYX2. PZY

- $\quad$ Pengaruh X2 ke Z melalui Y

Pengaruh langsung

$\mathrm{X} 2 \rightarrow \mathrm{Z} \Omega \mathrm{Y}=\mathrm{PZX} 2$. PYX2. PZY

Pengaruh tidak langsung

$\mathrm{X} 2 \longrightarrow \mathrm{Z} \Omega \mathrm{X} 1 \Omega \mathrm{Y}=\mathrm{PZX} 2 . \mathrm{rx} 1 \times 2 . \mathrm{PYX} 1 . \mathrm{PZY}$

2) Uji t

Uji t digunakan untuk melihat pengaruh secara parsial antara variabel eksogen dan variabel endogen. Berdasarkan hasil pengujian uji $\mathrm{t}$, maka akan diperoleh suatu hasil berupa $\mathrm{t}$ hitung yang akan dibandingkan dengan t tabel. Adapun rumus uji t adalah sebagai berikut : 


$$
t_{\text {hitung }}=\frac{r \sqrt{n-2}}{\sqrt{1-r^{2}}}
$$

Keterangan : $t=$ Nilai $t_{\text {hitung }} ; r=$ Koefisien korelasi $\left(r_{\text {hitung }}\right) ; \mathrm{n} n=$ Jumlah responden

- Nilai $t_{\text {hitung }}<t_{\text {tabel }}$ berarti Ho ditolak dan Hi diterima, artinya tidak terdapat pengaruh secara parsial.

3) Uji F

- Nilai $t_{\text {hitung }}>t_{\text {tabel }}$ berarti Ho diterima dan Hi ditolak, artinya terdapat pengaruh secara parsial.

Uji simultan (uji F) digunakan untuk melihat pengaruh secara simultan antara variabel eksogen dengan variabel endogen. Uji F dapat dilakukan dengan cara membandingkan antara Fhitung dengan Ftabel. Berikut ini adalah rumus untuk mengetahui nilai Fhitung :

$$
F=\frac{(n-k-1) R_{y x_{k}}^{2}}{k\left(1-R_{y x_{k}}^{2}\right)}
$$

Keterangan: $\mathrm{n}=$ jumlah sampel; $\mathrm{k}=$ jumlah variabel eksogen; $R_{y x_{k}}^{2}=R_{\text {Square }}$

Untuk uji F, kriteria yang dipakai adalah :

- Jika Fhitung > Ftabel, terima Ho, tolak Hi

- Jika Fhitung < Ftabel, terima Hi, tolak Ho.

\section{HASIL}

Analisis Jalur Pengaruh Fasilitas Kerja dan Kompetensi terhadap Kinerja melalui Kepuasan Kerja pada Kantor Kelurahan Sekecamatan Muara Bulian Kabupaten Batang Hari

Analisis ini, diperlukan nilai koefisien jalur baik jalur fasilitas kerja terhadap kepuasan kerja, maupun jalur kompetensi terhadap kepuasan kerja, jalur fasilitas kerja terhadap kinerja, jalur kompetensi terhadap kinerja, dan jalur kepuasan kerja terhadap kinerja. Pada pembahasan di atas telah diketahui koefisien masingmasing jalur. Berikut koefisien keseluruhan jalur dalam penelitian ini :

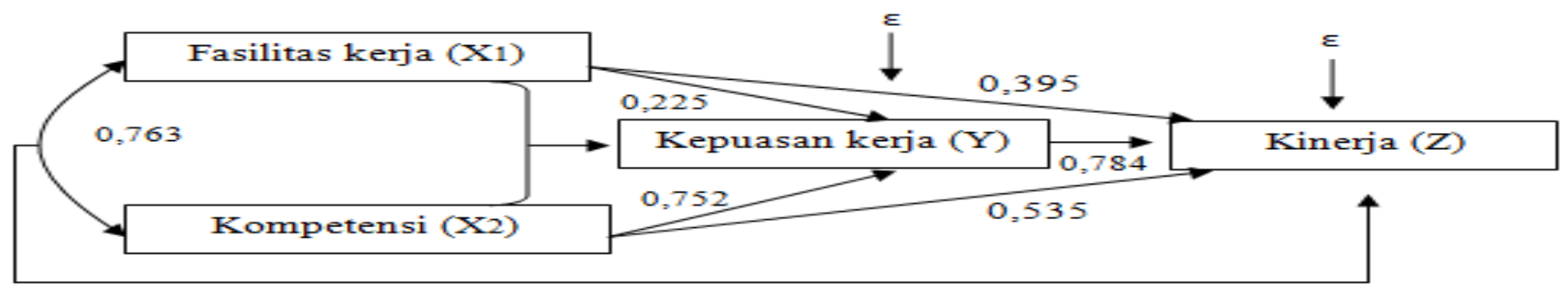

\section{Gambar 3.}

\section{Koefisien Jalur Secara Keseluruhan}

Berdasarkan pada gambar di atas, dapat kita lakukan perhitungan mengenai pengarauh fasilitas kerja dan kompetensi terhadap kinerja melalui kepuasan kerja. Berikut adalah perhitungan pengaruhnya :

a. Pengaruh fasilitas kerja $\left(\mathrm{X}_{1}\right)$ terhadap kinerja $(\mathrm{Z})$ melalui kepuasan kerja $(\mathrm{Y})$

$\mathrm{X}_{1} \Omega \mathrm{Y} \rightarrow \mathrm{Z}=\left(\mathrm{PZX}_{1}\right)\left(\mathrm{PYX}_{1}\right)(\mathrm{PZY})=0,395 \times 0,225 \times 0,784=0,06968$

b. Pengaruh kompetensi $\left(\mathrm{X}_{2}\right)$ terhadap kinerja $(\mathrm{Z})$ melalui kepuasan kerja $(\mathrm{Y})$

$\mathrm{X} 2 \Omega \mathrm{Y} \rightarrow \mathrm{Z}=\left(\mathrm{PZX}_{2}\right)\left(\mathrm{PYX}_{2}\right)(\mathrm{PZY})=0,535 \times 0,752 \times 0,784=0,31542$

c. Total pengaruh fasilitas kerja dan kompetensi terhadap kinerja melalui kepuasan kerja $=6,968 \%+31,542 \%=38,510 \%$

\section{Uji t dan Uji F}

Hipotesis menyatakan bahwa Fasilitas kerja dan kompetensi berpengaruh secara parsial dan signifikan terhadap kepuasan kerja pegawai pada Kantor Kelurahan Sekecamatan Muara Bulian Kabupaten Batang Hari. Berikut hasil pengujiannya : 
Tabel 1.

Nilai t Hitung dan $\mathbf{t}$ Tabel Fasilitas Kerja dan Kompetensi terhadap Kepuasan Kerja

\begin{tabular}{|c|c|c|c|}
\hline Variabel & t hitung & $t$ tabel & Sig. \\
\hline Fasilitas Kerja & 3,286 & 1,66864 & 0,002 \\
\hline Kompetensi & 10,989 & 1,66864 & 0,000 \\
\hline
\end{tabular}

Sumber : Data diolah

Pada tabel di atas, dapat diketahui bahwa :

- $\quad$ nilai t hitung untuk fasilitas kerja sebesar 3,286, nilai t tabel sebesar 1,66864, dan nilai Signifikan di bawah $0,05(0,002)$. Nilai t hitung > nilai t tabel $(3,286>1,66864)$, maka hipotesis yang menyatakan bahwa fasilitas kerja berpengaruh secara parsial dan signifikan terhadap kepuasan kerja pegawai pada Kantor Kelurahan Sekecamatan Muara Bulian Kabupaten Batang Hari diterima.

- $\quad$ Nilai t hitung untuk Kompetensi sebesar 10,989, nilai t tabel sebesar 1,66864, dan nilai Signifikan di bawah $0,05(0,000)$. Nilai t hitung > nilai t tabel $(10,989>1,66864)$, maka hipotesis yang menyatakan bahwa kompetensi berpengaruh secara parsial dan signifikan terhadap kepuasan kerja pegawai pada Kantor Kelurahan Sekecamatan Muara Bulian Kabupaten Batang Hari diterima.

Hipotesis menyatakan bahwa Fasilitas kerja dan kompetensi berpengaruh secara bersama-sama dan signifikan terhadap kepuasan kerja pegawai pada Kantor Kelurahan Sekecamatan Muara Bulian Kabupaten Batang Hari. Berikut hasil pengujiannya :

Tabel 2.

Nilai F Hitung dan F Tabel Fasilitas Kerja dan Kompetensi terhadap Kepusan Kerja

\begin{tabular}{rccc}
\hline Variabel & F hitung & F tabel & Sig. \\
\hline Kepuasan Kerja dan Kompetensi & 223,344 & 3,99 & 0,000 \\
\hline
\end{tabular}

Sumber: Data diolah

Pada tabel di atas, dapat diketahui bahwa nilai F hitung sebesar 223,344, nilai F tabel sebesar 3,99, dan nilai signifikan di bawah $0,05(0,000)$. Nilai $\mathrm{F}$ hitung $>$ nilai $\mathrm{F}$ tabel $(223,344>3,99)$, maka hipotesis yang menyatakan bahwa Fasilitas kerja dan kompetensi berpengaruh secara bersama-sama dan signifikan terhadap kepuasan kerja pegawai pada Kantor Kelurahan Sekecamatan Muara Bulian Kabupaten Batang Hari diterima.

Hipotesis menyatakan bahwa Fasilitas kerja dan kompetensi berpengaruh secara parsial dan signifikan terhadap kinerja pegawai pada Kantor Kelurahan Sekecamatan Muara Bulian Kabupaten Batang Hari. Berikut hasil pengujiannya:

Tabel 3.

Nilai t Hitung dan $\mathbf{t}$ Tabel Fasilitas Kerja dan Kompetensi terhadap Kinerja

\begin{tabular}{|c|c|c|c|}
\hline Variabel & t hitung & t tabel & Sig. \\
\hline Fasilitas Kerja & 4,205 & 1,66864 & 0,000 \\
\hline Kompetensi & 5,698 & 1,66864 & 0,000 \\
\hline
\end{tabular}

Sumber : Data diolah

Pada tabel di atas, dapat diketahui bahwa :

- $\quad$ nilai t hitung untuk fasilitas kerja sebesar 4,205, nilai t tabel sebesar 1,66864, dan nilai Signifikan di bawah $0,05(0,000)$. Nilai t hitung > nilai t tabel $(4,205>1,66864)$, maka hipotesis yang menyatakan bahwa fasilitas kerja berpengaruh secara parsial dan signifikan terhadap kinerja pegawai pada Kantor Kelurahan Sekecamatan Muara Bulian Kabupaten Batang Hari diterima.

- $\quad$ Nilai t hitung untuk Kompetensi sebesar 5,698, nilai t tabel sebesar 1,66864, dan nilai Signifikan di bawah $0,05(0,000)$. Nilai t hitung > nilai t tabel $(5,698>1,66864)$, maka hipotesis yang menyatakan bahwa kompetensi berpengaruh secara parsial dan signifikan terhadap kinerja pegawai pada Kantor Kelurahan Sekecamatan Muara Bulian Kabupaten Batang Hari diterima. 
Hipotesis menyatakan bahwa Fasilitas kerja dan kompetensi berpengaruh secara bersama-sama dan signifikan terhadap kinerja pegawai pada Kantor Kelurahan Sekecamatan Muara Bulian Kabupaten Batang Hari. Berikut hasil pengujiannya :

Tabel 4.

Nilai F Hitung dan F Tabel Fasilitas Kerja dan Kompetensi terhadap Kinerja

\begin{tabular}{rccc}
\hline Variabel & F hitung & F tabel & Sig. \\
\hline Kepuasan Kerja dan Kompetensi & 103,739 & 3,99 & 0,000 \\
\hline
\end{tabular}

Sumber : Data diolah

Pada tabel di atas, dapat diketahui bahwa nilai F hitung sebesar 103,739, nilai F tabel sebesar 3,99, dan nilai signifikan di bawah $0,05(0,000)$. Nilai $F$ hitung $>$ nilai $F$ tabel $(223,344>3,99)$, maka hipotesis yang menyatakan bahwa fasilitas kerja dan kompetensi berpengaruh secara bersama-sama dan signifikan terhadap kinerja pegawai pada Kantor Kelurahan Sekecamatan Muara Bulian Kabupaten Batang Hari diterima.

Hipotesis menyatakan kepuasan kerja berpengaruh secara parsial dan signifikan terhadap kinerja pegawai pada Kantor Kelurahan Sekecamatan Muara Bulian Kabupaten Batang Hari. Berikut hasil pengujiannya :

Tabel 5.

Nilai t Hitung dan t Tabel Kepuasan Kerja terhadap Kinerja

\begin{tabular}{cccc}
\hline Variabel & t hitung & t tabel & Sig. \\
\hline Kepuasan Kerja & 10,177 & 1,66864 & 0,000 \\
\hline
\end{tabular}

Sumber : Data diolah

Pada tabel di atas, dapat diketahui bahwa nilai t hitung untuk kepuasan kerja sebesar 10,177, nilai t tabel sebesar 1,66864, dan nilai Signifikan di bawah $0,05(0,000)$. Nilai $t$ hitung $>$ nilai $t$ tabel $(10,177>1,66864)$, maka hipotesis yang menyatakan bahwa kepuasan kerja berpengaruh secara parsial dan signifikan terhadap kinerja pegawai pada Kantor Kelurahan Sekecamatan Muara Bulian Kabupaten Batang Hari diterima.

\section{SIMPULAN}

1. Fasilitas kerja dan kompetensi berpengaruh secara parsial dan signifikan terhadap kepuasan kerja pada Kantor Kelurahan Sekecamatan Muara Bulian Kabupaten Batang Hari

2. Fasilitas kerja dan kompetensi berpengaruh secara simultan dan signifikan terhadap kepuasan kerja pada Kantor Kelurahan Sekecamatan Muara Bulian Kabupaten Batang Hari.

3. Fasilitas kerja dan kompetensi berpengaruh secara parsial dan signifikan terhadap kinerja pada Kantor Kelurahan Sekecamatan Muara Bulian Kabupaten Batang Hari

4. Fasilitas kerja dan kompetensi berpengaruh secara simultan dan signifikan terhadap kinerja pada Kantor Kelurahan Sekecamatan Muara Bulian Kabupaten Batang Hari.

5. Untuk mengetahui bahwa kepuasan kerja berpengaruh secara parsial dan signifikan terhadap kinerja pada Kantor Kelurahan Sekecamatan Muara Bulian Kabupaten Batang Hari.

6. Adapun pengaruh fasilitas kerja dan kompetensi terhadap kinerja melalui kepuasan kerja dapat dilihat dari total pengaruh fasilitas kerja dan kompetensi terhadap kinerja melalui kepuasan kerja. Berdasarkan total pengaruh, pengaruh fasilitas kerja dan kompetensi terhadap kinerja melalui kepuasan kerja sebesar 38,51\%.

\section{DAFTAR PUSTAKA}

Adisetiawan, R., 2014, Performance Mahasiswa Fakultas Ekonomi Universitas Batanghari Jambi, Jurnal Ilmiah Universitas Batanghari Jambi, 14(3), 1-10

Anak Agung Ngurah Bagus Dhermawan, dkk. 2012. Pengaruh Motivasi, Lingkungan Kerja, Kompetensi, Dan Kompensasi Terhadap Kepuasan Kerja Dan Kinerja Pegawai Di Lingkungan Kantor Dinas Pekerjaan 
Umum Provinsi Bali. Bali : OJS Universitas Udayana

Awaludin K., dkk. 2013. Pengaruh Pemberian Fasilitas, Tingkat Pendidikan Dan Disiplin Kerja Terhadap Peningkatan Kinerja Pegawai Pada Badan Busat Statistik Kabupaten Maros. Program Magister Manajemen Universitas Hasanuddin

Dahlias, Apri dan Ibrahim Mariaty. 2015. Pengaruh Fasilitas Kerja terhadap Kepuasan Kerja Karyawan pada

PT. Bank Riau Kepri Cabang Teluk Kuantan Kabupaten Kuantan Singingi. JOM FISIP Vol. 3 No. 2-

Oktober 2016

Departemen Pend. Nasional. 2008. Kamus Besar Bahasa Indonesia. Jakarta: PT Gramedia Pustaka Utama.

Fred, Luthans. 1998. Organizational Behavior: Instuctor's Resources Manual and Test Bank. New York:

International Book Company

Fuad Mas'ud. 2004. Survei Diagnosis Organisasional. Semarang : Badan Penerbit Universitas Diponegoro

Gibson, James L. et al. 2004. Organisasi : Perilaku Struktur Dan Proses. Alih bahasa : Ir. Hunuk

Adiarni,MM. Jakarta : Bina Rupa Aksara

Ghozali, Imam. 2011. Aplikasi Analisis Multivariate dengan Program SPSS. Semarang: Badan Penerbit

Universitas Diponegoro.

Gomes, Faustino Cardoso. 2003. Manajemen Sumber Daya Manusia. Yogyakarta : ANDI

Handoko, T. Hani. 2003. Manajemen. Yogyakarta: BPFE.

2008. Manajemen Personalia dan Sumber Daya Manusia. Yogyakarta: BPFE.

Hartanto, L. 2000. Manajemen Personalia. Jakarta: PT. Radjagrafindo

Hasibuan, Malayu. 2007. Organisasi dan Motivasi Dasar Peningkatan Produktivitas. Jakarta:

PT. Bumi Aksara.

2008. Manajemen Sumber Daya Manusia. Jakarta: Bumi Aksara.

Hutapea, Parulian dan Nurianna Thoha. 2008. Kompetensi Plus. PT. Gramedia Pustaka Utama: Jakarta

Kaswan. 2012. Manajemen Sumber Daya Manusia untuk Keunggulan Bersaing Organisasi. Yogyakarta:

Graha Ilmu.

Kreitner, Robert dan Kinicki, Angelo. 2005. Perilaku Organisasi. Jakarta: Salemba Empat

Lund Daulatram. 2003. Organization Culture and Job Satisfaction. Journal of business and Industrial

Marketing. Vol 18 No 32003 pp.219-236.

Lupiyoadi, Hamdani. 2006. Manajemen Pemasaran Jasa, Edisi Kedua. Jakarta : Penerbit Salemba Empat

Mangkunegara Anwar.P (2000). Manajemen Kepegawaian Dan Sumber Daya Manusia, Bandung

Rosda Karya.

. 2009. Manajemen Sumber Daya Manusia Perusahaan. Bandung: PT. Remaja

Mariam, Rani. 2009. Pengaruh Gaya Kepemimpinan Dan Budaya Organisasi Terhadap Kinerja Karyawan

Melalui Kepuasan Kerja Karyawan Sebagai Variabel Intervening Studi Pada Kantor Pusat PT.Asuransi

Jasa Indonesia (Persero). Semarang : UNDIP

Moenir. 2003. Pendekatan Manusiawi dan Organisasi terhadap Pembinaan Kepegawaian. Jakarta: PT

Gunung Agung.

Moeheriono. 2009. Pengukuran Kinerja Berbasis Kompetensi. Bogor. Ghalia Indonesia

Riduwan. 2012. Skala Pengukuran Variabel-Variabel Penelitian. Bandung: Alfabeta

Robbins SP dan Judge. 2002. Perilaku Organisasi. Jakarta : Salemba Empat

Rosidah dan Ambar T. Sulistiyani. 2003. Manajemen Sumber Daya Manusia. Cetakan. Pertama. Penerbit Graha Ilmu.

Siagian, Sondang P. 2003.Teori dan Praktek Kepemimpinan, Jakarta: PT. RINEKA CIPTA

Sudarmanto. 2009. Kinerja dan Pengembangan Kompetensi SDM. Yogyakarta: Pustaka Pelajar.

Sudrajat. Subana M. dan Marsetiyo Rahardi. 2000. Statistik Pendidikan. Pustaka: Bandung

Sugiyono. 2010. Metode Penelitian Kuantitatif Kualitatif dan R\&D. Bandung: Alfabeta.

Suharsimi, Arikunto. 2010. Prosedur Penelitian Suatu Pendekatan Praktik. Jakarta: Rineka Cipta

Sunyoto, Danang. 2013. Teori, Kuesioner dan Analisis Data Sumber Daya Manusia. Yogyakarta: CAPS.

Supriyanto, Yudi. 2015. Kompetensi Dan Komitmen Organisasional Terhadap Kepuasan Kerja Dan Kinerja

Pengaruh Fasilitas Kerja dan Kompetensi terhadap Kepuasan Kerja Pegawai dan Dampaknya Terhadap Kinerja Pegawai Kantor

Kelurahan Sekecamatan Muara Bulian Kabupaten Batang Hari 
Karyawan Koperasi. Prosiding Seminar Nasional 9 Mei 2015

Sutrisno, Edy. 2010. Manajemen Sumber Daya Manusia. Jakarta : Kencana Prenada Media Group

Umar, Husein. 2002. Metode Riset Komunikasi Organisasi. Jakarta: PT Gramedia Pustaka Utama.

Wibowo. 2007. Manajemen Kinerja. PT. Raja Grafindo Parsada: Jakarta 